\title{
GROWTH AND PHYSIOLOGY OF Annona squamosa L. UNDER DIFFERENT IRRIGATION DEPTHS AND PHOSPHATE FERTILIZATION
}

\author{
CRESCIMENTO E FISIOLOGIA DE MUDAS DE Annona squamosa L. SOB \\ DIFERENTES LÂMINAS DE IRRIGAÇÃO E ADUBAÇÃO FOSFATADA
}

\author{
Rômulo Carantino Lucena MOREIRA ${ }^{1}$; Marcos Eric Barbosa BRITO ${ }^{2}$; \\ Pedro Dantas FERNANDES ${ }^{3}$; Francisco Vanies da Silva $\mathrm{SÁ}^{4}$; \\ Luderlândio de Andrade SILVA ${ }^{1}$; Carlos Jardel Andrade OLIVEIRA ${ }^{5}$; \\ Luana Lucas de Sá Almeida VELOSO ${ }^{1}$; Thaís Batista de QUEIROGA ${ }^{6}$
}

1. Doutorando em Engenharia Agrícola, Universidade Federal de Campina Grande - UFCG, Campina Grande, PB, Brasil. romulocarantino@gmail.com; 2. Professor Doutor da Universidade Federal de Sergipe - UFS, Campus do Sertão, Nossa Senhora da Glória, SE, Brasil; 3. Professor Doutor, UFCG, Campina Grande, PB, Brasil; 4. Doutor em Engenharia Agrícola, Pós-Doutorando em Manejo de Solo e Água PNPD/CAPES, UFERSA, Universidade Federal Rural do Semi-Árido - UFERSA, Mossoró-RN, Brasil; 5. Doutorando em Agronomia, Universidade Federal da Paraíba - UFPB, Campus II, Areia-PB, Brasil; 6. Mestranda em Horticultura Tropical, UFCG, Pombal-PB, Brasil.

ABTRACT: This study aimed to evaluate the growth and physiology of Annona squamosa seedlings under increasing irrigation depths and phosphorus doses. The experiment was conducted in protected environment, evaluating five irrigation depths and four $\mathrm{P}_{2} \mathrm{O}_{5}{ }^{-}$doses, arranged in $5 \times 4$ factorial scheme, in randomized blocks, with four replicates and one plant per plot. Treatments were irrigation depths of 60, 80, 100,120 and $140 \%$ of the real evapotranspiration of the seedlings - ETr and phosphorus doses of 0, 350, 700 and $1050 \mathrm{mg} \mathrm{dm}^{-3}$ of $\mathrm{P}_{2} \mathrm{O}_{5}$. Plants were evaluated at 120 days after transplanting with respect to growth, gas exchanges, leaf water potential and total dry matter accumulation. Phosphorus dose of $350 \mathrm{mg} \mathrm{dm}^{-3}$ promotes satisfactory dry matter accumulation for A. squamosa seedlings, especially under $100 \%$ ETr irrigation. Leaf water potential and gas exchanges of $A$. squamosa are affected by water stress, through both lack and excess of water. Stomatal conductance is the variable most sensitive to the lack of water, whereas photosynthesis and water use efficiency are the most sensitive to the excess of water. Irrigation depth of $100 \% \mathrm{ETr}$ is ideal to produce A. squamosa seedlings, but the irrigation depth of $80 \%$ ETr can be used to produce these seedlings, disregarding small losses of growth.

KEYWORDS: Annonaceae. Water availability. Gas exchanges. Soil fertility

\section{INTRODUCTION}

Annona squamosa L., whose fruit is popularly known as 'pinha', 'fruta do conde', 'ateira' or 'anona', is a fruit species belonging to the Annonaceae family with great socioeconomic potential in Brazil and worldwide (LEMOS, 2014). This crop is in full expansion in the country due to the great attractiveness of its fruits, and the Northeast region is the main producer, especially the states of Alagoas, Bahia, Ceará and Pernambuco, where there may be two harvests per year if cultivation practices such as fertilization and irrigation are adopted (PEREIRA et al., 2010; MEDEIROS et al, 2014).

In addition, Annonaceae species are considered as of easy adaptability to different edaphoclimatic conditions, and some species grow well under hot and humid climates of typically tropical zones, showing good levels of yield, being commercially cultivated in several parts of the world due to the profitability achieved (SÃO JOSÉ et al., 2014).

In semi-arid regions, climate conditions play a decisive role in crop irrigation management, to the point of causing restriction in the yield, compromising the efficiency of the agricultural production system (AZEVEDO et al., 2014). Given the existing scarcity of water in these regions, in drought periods it is important to consider the efficiency in the use of this resource, either in selecting the amount of water to be applied or in the management adopted (VICENTE et al., 2015). In response to the lack of water, plants trigger various physiological events among which the osmotic adjustment is the most common, aiming to maintain water potential and cell turgor close to adequate levels (PEREIRA et al., 2012; ASHRAF; HARRIS, 2013).

Besides adequate irrigation management, fertilization is another decisive practice to increase crop yield. In a study evaluating phosphate 
fertilization on the production of A. squamosa seedlings, Freitas et al. (2013) observed that this nutrient is crucial for seedling development, due to its function in root growth, thus allowing for greater exploration of the soil and water absorption by the plant.

In semi-arid regions, there is a predominance of tropical soils with low natural availability of phosphorus and such lack requires greater caution with respect to phosphate fertilization management in these regions because the low availability of the nutrient associated with the water limitations found negatively affect crop development (LIMA et al., 2017; SÁ et al., 2017).

Given the above, this study aimed to evaluate the growth and physiology of A. squamosa seedlings under increasing irrigation depths and phosphorus doses.

\section{MATERIAL AND METHODS}

The experiment was conducted from October 2015 to February 2016 for 120 days in a protected environment at the Center of Sciences and Agri-Food Technology (CCTA) of the Federal University of Campina Grande, municipality of Pombal - PB, Brazil, located at geographic coordinates $6^{\circ} 48^{\prime} 16^{\prime \prime} \mathrm{S}$ and $37^{\circ} 49^{\prime} 15^{\prime \prime} \mathrm{W}$ at altitude of $174 \mathrm{~m}$.

Temperature and rainfall were monitored along the experimental period; maximum temperature varied from 30 to $39{ }^{\circ} \mathrm{C}$, whereas minimum temperature varied from 15 to $26^{\circ} \mathrm{C}$, and their mean values were respectively equal to $34.1 \pm 1.3$ and $21.4 \pm 2.0^{\circ} \mathrm{C}$, recorded from beginning to the end of the experiment.

The experimental design was randomized blocks in a $5 \times 4$ factorial scheme, comprising four blocks and one plant per plot, corresponding to five irrigation depths $(60,80,100,120$ and $140 \%$ of real evapotranspiration - ETr) and four phosphorus doses $(\mathrm{D} 1=0 ; \mathrm{D} 2=350 ; \mathrm{D} 3=700$ and $\mathrm{D} 4=1050$ $\mathrm{mg} \mathrm{dm}^{-3}$ of $\mathrm{P}_{2} \mathrm{O}_{5}$ ), in the form of single superphosphate $\left(18 \% \quad \mathrm{P}_{2} \mathrm{O}_{5}, 20 \% \mathrm{Ca}^{2+}, 12 \% \mathrm{~S}\right)$, ground, applied 30 days before transplanting the seedlings.

Sowing was carried out on polyethylene trays containing 162 cells with capacity for $0.05 \mathrm{dm}^{3}$ each, by planting one seed per cell, which was filled with commercial substrate based on pine bark, humus and vermiculite, at 1:1:1 proportion. Seedlings remained in tray cells until the appearance of the third true leaf, at 30 days after sowing (DAS). Then, they were transplanted to $3.78 \mathrm{dm}^{3}$ lysimeters containing substrate at 2:1:1 proportion: two parts of soil, one part of washed sand and one part of bovine manure. The chemical characteristics of this substrate are presented in Table 1. Plants were acclimated for seven days, maintaining soil moisture close to field capacity through daily irrigations, determined based on drainage lysimetry (BERNARDO et al., 2008), and the irrigation depths began to be applied 8 days after transplanting (DAT).

Table 1. Physical-chemical characterization of the substrate used to produce A. squamosa seedlings

\begin{tabular}{|c|c|c|c|c|c|c|c|c|}
\hline \multirow{2}{*}{$\begin{array}{l}\text { Textural } \\
\text { classification }\end{array}$} & \multirow{2}{*}{$\begin{array}{l}\text { Soil } \\
\text { Density } \\
\mathrm{g} \mathrm{cm}^{-3}\end{array}$} & \multirow{2}{*}{$\begin{array}{l}\text { Total } \\
\text { porosity } \\
\%\end{array}$} & \multirow{2}{*}{$\begin{array}{l}\text { Organic } \\
\text { matter } \\
\mathrm{g} \mathrm{kg}^{-1}\end{array}$} & \multirow[b]{2}{*}{$\begin{array}{l}\mathrm{P} \\
\mathrm{mg} \mathrm{dm^{-3 }}\end{array}$} & \multicolumn{4}{|c|}{ Sortive complex } \\
\hline & & & & & $\mathrm{Ca}^{2+}$ & $\begin{array}{r}\mathrm{Mg}^{2+} \\
-\mathrm{cmol}_{\mathrm{c}}\end{array}$ & $\begin{array}{l}\mathrm{Na}^{+} \\
\mathrm{n}^{-3}--\end{array}$ & $\mathrm{K}^{+}$ \\
\hline Sandy franc & 1.38 & 47.00 & 32 & 17 & 5.4 & 4.1 & 2.21 & 0.28 \\
\hline \multicolumn{9}{|l|}{ Saturation extract } \\
\hline $\begin{array}{ll}\text { pHse } & \begin{array}{l}\text { ECse } \\
\mathrm{dS} \mathrm{m}^{-1}\end{array} \\
\end{array}$ & $\mathrm{Ca}^{2+}$ & $\mathrm{K}^{+}$ & $\begin{array}{lc}\mathrm{Na}^{+} \mathrm{Cl}^{-} \\
-\mathrm{mmol}_{\mathrm{c}} \mathrm{dm}^{-3}\end{array}$ & $\mathrm{SO}_{4}{ }^{2-}$ & $\mathrm{CO}_{3}{ }^{2-}$ & $\mathrm{HCO}_{3}$ & \multicolumn{2}{|c|}{$\begin{array}{l}\text { Saturation } \\
\%\end{array}$} \\
\hline 7.41 & 2.50 & 3.75 & 3.02 & 3.10 & 0.00 & 5.63 & 27. & \\
\hline
\end{tabular}

Organic matter: Walkley-Black wet digestion; $\mathrm{Ca}^{2+}$ and $\mathrm{Mg}^{2+}$ extracted with $1 \mathrm{~mol} \mathrm{~L}^{-1} \mathrm{KCl}$ at $\mathrm{pH} 7.0 ; \mathrm{Na}^{+}$and $\mathrm{K}^{+}$extracted with $1 \mathrm{~mol} \mathrm{~L}^{-1}$ $\mathrm{NH}_{4} \mathrm{OAc}$ at $\mathrm{pH} 7.0$; ECse - electrical conductivity of the soil saturation extract.

Drained water volume was collected by zinc gutters to determine plant water consumption in the treatments of $120 \%$ field capacity, obtained by the difference between applied and drained volumes, resulting in the consumed volume as the $100 \%$ water depth is multiplied by the factors $0.6,0.8,1.0$, 1.4 to obtain water depths of $60,80,100$ and $140 \%$ field capacity, respectively.

At 120 DAT, when seedlings were ready to be taken to the field, the following parameters were determined: plant height $(\mathrm{PH})$, measured with a graduated ruler as the main stem length from the base to the tip; number of leaves (NF), determined by counting the photosynthetically active leaves; and stem diameter (SD), measured using a digital caliper and expressed in $\mathrm{mm}$.

Leaf water potential was determined at 120 DAT by collecting one sample in each plot from 4 to 6 a.m. and placing it in a Scholander pressure bomb to measure the negative hydrostatic pressure 
(tension) existing in the xylem of many plants, according to Scholander et al. (1965).

At 120 DAT, gas exchanges were measured in the plants using a portable photosynthesis meter (LCPro+ - ADC BioScientific Ltd), operating with controlled temperature of $25{ }^{\circ} \mathrm{C}$, irradiation of 1200 $\mu$ mol photons $\mathrm{m}^{-2} \mathrm{~s}^{-1}$ and $\mathrm{CO}_{2}$ from the environment at $3 \mathrm{~m}$ height from soil surface, to obtain $\mathrm{CO}_{2}$ assimilation rate $(A)\left(\mu \mathrm{mol} \mathrm{m} \mathrm{m}^{-2} \mathrm{~s}^{-1}\right)$, transpiration $(E)$ (mol of $\mathrm{H}_{2} \mathrm{O} \mathrm{m}^{-2} \mathrm{~s}^{-1}$ ), stomatal conductance (gs) (mmol of $\mathrm{H}_{2} \mathrm{Om}^{-2} \mathrm{~s}^{-1}$ ) and internal $\mathrm{CO}_{2}$ concentration $(\mathrm{Ci})$, in the third leaf from the apex. These data were used to calculate intrinsic water use efficiency (WUEi) (A/E) $\left[\left(\mu \mathrm{mol} \mathrm{m} \mathrm{s}^{-2} \mathrm{~s}^{-1}\right)\left(\mathrm{mol} \mathrm{H} \mathrm{H}_{2} \mathrm{O}\right.\right.$ $\left.\left.\mathrm{m}^{-2} \mathrm{~s}^{-1}\right)^{-1}\right]$ and instantaneous carboxylation efficiency (EiCi) (SÁ et al., 2017).

Total dry matter (TDM) corresponded to the sum of leaf dry matter, stem dry matter and root dry matter, which were obtained by drying the material from these plant parts in a forced-air oven at $65^{\circ} \mathrm{C}$ until constant weight.

The data were subjected to analysis of variance by $\mathrm{F}$ test and means were compared by regression using the program Sisvar, version 5.1 (FERREIRA, 2011).

\section{RESULTS AND DISCUSSION}

The interaction between irrigation depths and phosphate fertilization had significant $(\mathrm{p}<0.05)$ effect on total dry matter. For leaf water potential, internal $\mathrm{CO}_{2}$ concentration, transpiration, $\mathrm{CO}_{2}$ assimilation rate, stomatal conductance, intrinsic water use efficiency, plant height, number of leaves and stem diameter, there was only significant $(\mathrm{p}<$ 0.05 ) effect of irrigation depths. Instantaneous carboxylation efficiency was not influenced by the studied factors (Table 2).

Table 2. Significance of $\mathrm{F}$ test for leaf water potential ( $\Psi \mathrm{f})$, internal $\mathrm{CO}_{2}$ concentration $(\mathrm{Ci})$, transpiration (E), $\mathrm{CO}_{2}$ assimilation rate (A), stomatal conductance (gs), intrinsic water use efficiency (WUEi) (A/E), instantaneous carboxylation efficiency (EiCi), plant height (PH), number of leaves (NL), stem diameter (SD) and total dry matter (TDM) of the A. squamosa under irrigation depths and phosphate fertilizer doses at 120 days after treatments began to be applied.

\begin{tabular}{|c|c|c|c|c|c|c|c|c|c|c|c|c|}
\hline \multirow{2}{*}{ FV } & \multirow{2}{*}{ GL } & \multicolumn{11}{|c|}{ Significância do teste 'F' } \\
\hline & & $\Psi \mathrm{f}$ & $\mathrm{Ci}$ & $E$ & A & Gs & WAEi & $\mathrm{EiCi}$ & PH & NL & SD & TDM \\
\hline Bloco & 3 & $*$ & $*$ & $*$ & $*$ & $*$ & $*$ & ns & ns & ns & ns & $*$ \\
\hline Lâm (L) & 4 & $*$ & $*$ & $*$ & $*$ & $*$ & $*$ & ns & $*$ & $*$ & $*$ & $*$ \\
\hline Dose (D) & 3 & ns & ns & ns & ns & ns & ns & ns & ns & ns & ns & ns \\
\hline$L \times D$ & 12 & ns & ns & ns & ns & ns & ns & ns & ns & ns & ns & $*$ \\
\hline Resíduo & 57 & - & - & - & - & - & - & - & - & - & - & - \\
\hline C. V. (\%) & & 18.64 & 7.22 & 9.35 & 13.84 & 13.19 & 11.33 & 17.81 & 5.80 & 5.48 & 7.39 & 7.39 \\
\hline Média Gera & & 4.28 & 260.11 & 2.43 & 10.57 & 0.19 & 4.39 & 0.04 & 98.82 & 39.78 & 9.81 & 9.81 \\
\hline
\end{tabular}

Increase in irrigation depths up to the maximum estimated value of $94 \%$ increased $\mathrm{CO}_{2}$ assimilation rate to $10.775 \mu \mathrm{mol} \mathrm{m} \mathrm{m}^{-2} \mathrm{~s}^{-1}$, but irrigations using higher water depths, especially from $120 \% \mathrm{ETr}$, reduced the net photosynthesis of the A. squamosa seedlings. Such reduction, due to irrigation depths above $94 \% \mathrm{ETr}$, is an indication of sensitivity of the A. squamosa plants to excess water because the $\mathrm{CO}_{2}$ assimilation of plants subjected to $140 \% \mathrm{ETr}$ is $5.51 \%$ lower than that of plants under $60 \% \mathrm{ETr}$ (Figure 1A).

Stomatal conductance $(g s)$ showed a quadratic response similar to that of $\mathrm{CO}_{2}$ assimilation rate, in which the increase in irrigation depths up to $108 \%$ ETr led to highest stomatal conductance, $0.2008 \mathrm{mmol}$ of $\mathrm{H}_{2} \mathrm{O} \mathrm{m} \mathrm{m}^{-2}$. From $108 \%$ ETr on, there was a reduction in stomatal conductance (Figure 1B).
In response to water stress by lack (60 and $80 \%$ ETr) or excess (120 and 140\% ETr), there was a reduction in the photosynthesis of the A. squamosa seedlings caused by the increase in the resistance to $\mathrm{CO}_{2}$ diffusion through the stomata and mesophyll (BENLLOCH-GONZÁLEZ et al., 2010; GALMÉS et al., 2011). Increment in the resistance to $\mathrm{CO}_{2}$ diffusion may be due to stomatal closure in response to the decrease in leaf water potential (ARAÚJO; DEMINICIS, 2009; ENDRES et al., 2010).

Transpiration was stimulated by irrigation depths, reaching highest value of $2.85 \mathrm{mmol}$ of $\mathrm{H}_{2} \mathrm{O}$ $\mathrm{m}^{-2} \mathrm{~s}^{-1}$ at the maximum estimated water depth of $135 \%$ ETr (Figure 1C). Water tends to change from liquid to gaseous state due to the difference in water vapor concentration between leaf intercellular spaces and the external atmospheric mass (TAIZ et al., 2015). Silva et al. (2015a) reported a behavior usually exhibited by plants, which show high 
transpiration rates so that, as water becomes scarce in the soil, the plant begins to reduce its
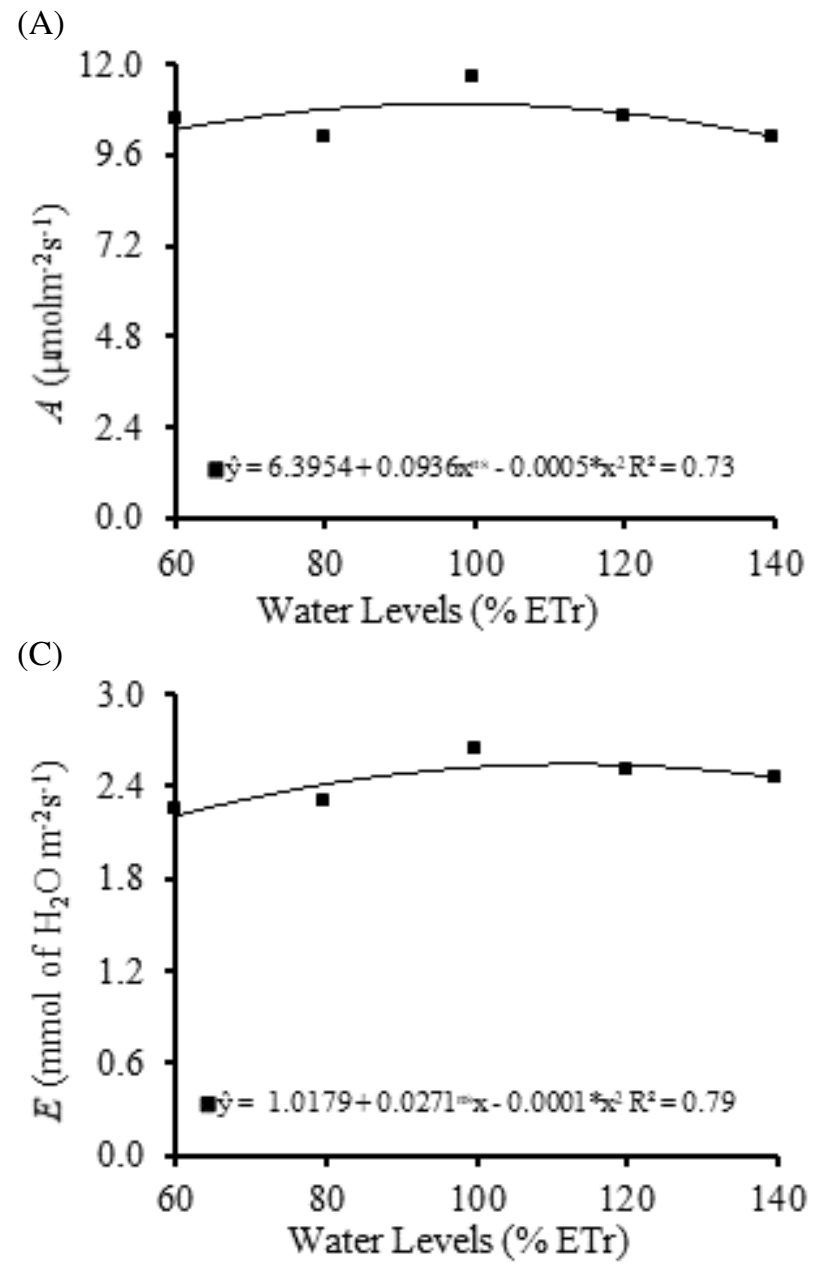

(E)

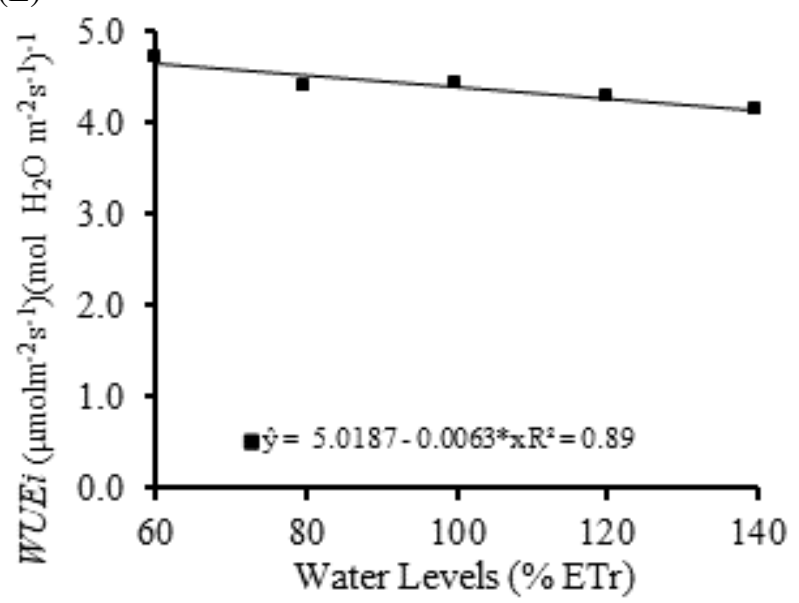

transpiration rate to minimize water loss and save the water available in the soil.
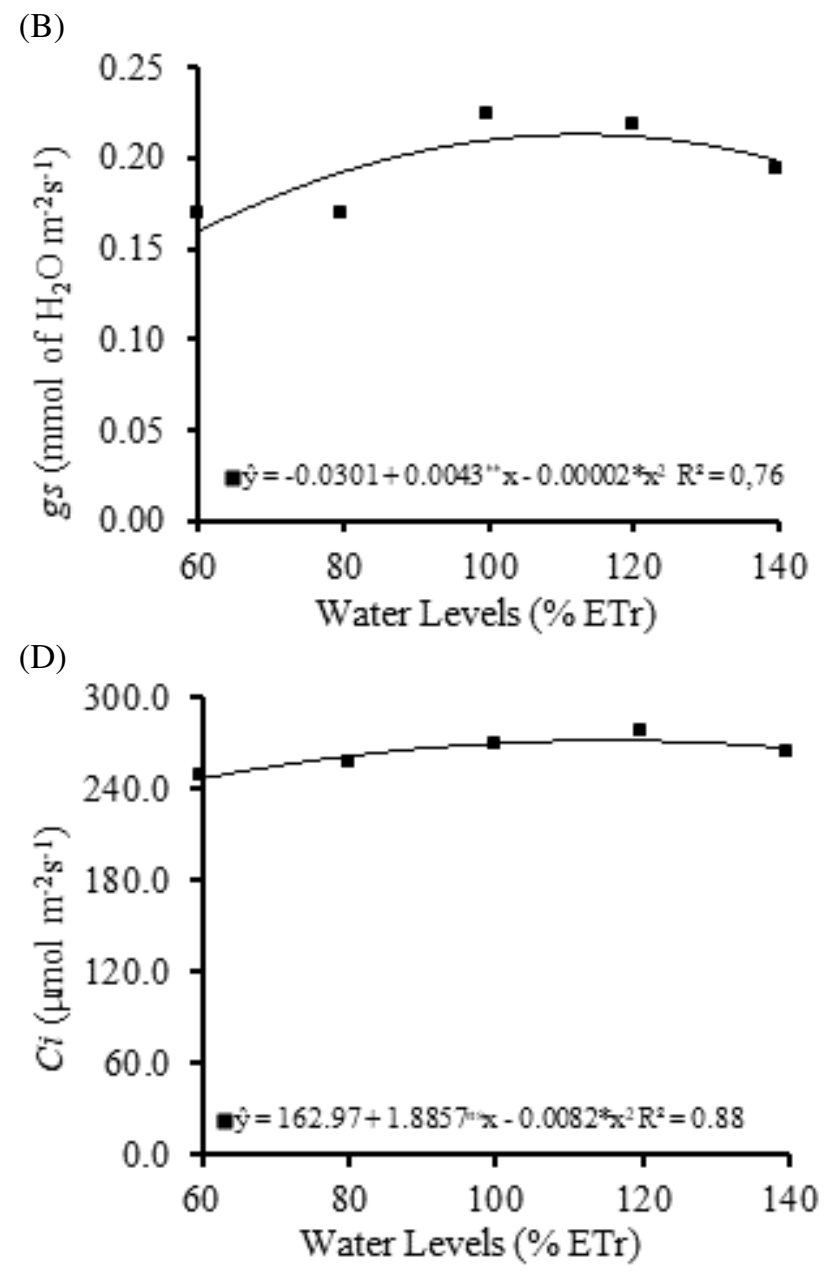

(F)

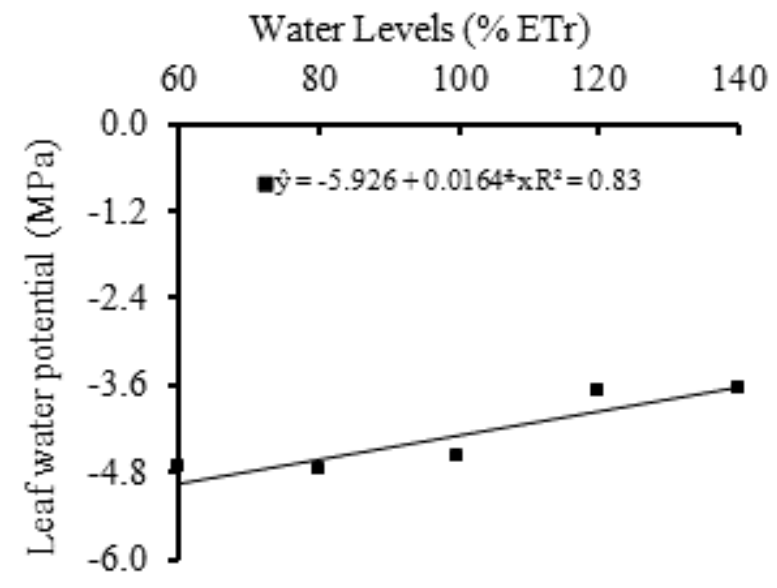

Figure 1. $\mathrm{CO}_{2}$ assimilation rate - $A(\mathrm{~A})$, stomatal conductance - $g s(\mathrm{~B})$, transpiration - $E(\mathrm{C})$, internal $\mathrm{CO}_{2}$ concentration - $C i$ (D), intrinsic water use efficiency - WUEi (E) and leaf water potential (F) of Annona squamosa L. seedlings as a function of irrigation depths at 120 days after treatments began to be applied.

Increase in irrigation depths led to increments in internal $\mathrm{CO}_{2}$ concentration $(\mathrm{Ci})$ up to a maximum of $271.38 \mu \mathrm{mol} \mathrm{m} \mathrm{m}^{-2} \mathrm{~s}^{-1}$, obtained in seedlings irrigated with the estimated water depth of
$115 \%$ ETr (Figure 1D). Such behavior is common because the internal $\mathrm{CO}_{2}$ concentration follows the same trend of stomatal conductance and, consequently, a limitation in the stomata would be 
the limiting factor for adequate development, since the larger the stomatal opening, the greater $\mathrm{CO}_{2}$ diffusion to the substomatal chamber (TAIZ et al., 2015). According to Bosco et al. (2009), stomatal closure and the consequent reduction in the normal $\mathrm{CO}_{2}$ flux towards the site of carboxylation are the main responsible for the reduction in photosynthesis, as observed in the present study.

Intrinsic water use efficiency decreased linearly at a rate of $0.006\left(\mu \mathrm{molm}^{-2} \mathrm{~s}^{-1}\right)\left(\mathrm{mol} \mathrm{H}_{2} \mathrm{O} \mathrm{m}\right.$ $\left.{ }^{2} \mathrm{~s}^{-1}\right)^{-1}$ per unit increase in irrigation depths, with losses of $10.86 \%$ between seedlings irrigated with 60 and $140 \%$ ETr (Figure 1E). In response to the lack of water, plants trigger several physiological events, such as the stomatal closure observed in plants irrigated with 60 and $80 \%$ ETr, probably trying to obtain better osmotic adjustment to maintain water potential and cell turgor close to adequate levels (PEREIRA et al., 2012). Despite that, under excess water conditions, stomatal closure did not contribute to increasing water use efficiency, as observed under conditions of water stress by lack of water.

Excess of water was more harmful to photosynthesis, consequently limiting water use efficiency. Batista et al. (2008) studying Cecropia pachystachya, and Oliveira \& Gualtieri (2017), studying Tabebuia aurea, found reductions in stomatal conductance of plants subjected to flood, which also led to reduction in their photosynthetic activity, corroborating the result observed in the present study. Although the period of saturation in our experiment was short, because of the drainage system, it was sufficient to reduce the photosynthetic activity of $A$. squamosa plants, but it did not affect carboxylation efficiency, indicating that this stress was not able to cause more severe alterations, for instance on the supply of ATP and NADPH to the functioning of the enzyme Ribulose1,5-bisphosphate carboxylase/oxygenase (MACHADO et al., 2010; SÁ et al., 2017). The effects mainly occurred on the stomata, and the reduction in photosynthesis followed stomatal closure and the decrease in $\mathrm{CO}_{2}$ influx (Figures 1A, $\mathrm{B}$ and $\mathrm{D})$.

Leaf water potential ( $\Psi f$ ) increased linearly as a function of the increase in irrigation depths
(Figure 1F), with increments of $0.33 \mathrm{KPa}$ for every $20 \%$ increase in irrigation depth. Lowest water potentials occurred in the leaves of plants irrigated with $60 \%$ ETr, coinciding with the low levels of transpiration, stomatal conductance and photosynthesis, denoting limiting conditions of water availability to the plants. Such reduction in leaf water potential, according to Martins et al. (2010), results in a short water deficit, caused by the high evaporative demand of the atmosphere, and can be related to the capacity of the transpiration to exceed water absorption by roots.

Increase in irrigation depths (\% ETr) linearly stimulated seedlings growth in height, number of leaves and stem diameter, which increased respectively by $3.27 \mathrm{~cm}, 0.7$ leaves and $0.29 \mathrm{~mm}$ for every $20 \%$ increase in irrigation depth (Figure 2A, B and C). Plants favored by greater water availability tend to have higher potential for cell turgor, distension of the protoplasmic layer and the wall of a plant cell due to its liquid content, compared with those under water deficit (TAIZ et al., 2015), and consequently greater growth. It is important to point out that, despite the reduction in photosynthetic activity, the growth of the $A$. squamosa seedlings was not negatively affected by the increase in irrigation depths, during the stage of seedling production. Similar results were observed by Silva et al. (2015b) and Queiroz et al. (2017) in seedlings of Surinam cherry and Eucalyptus globulus under water stress, respectively, whose growth was also reduced by the reduction in irrigation depths.

The highest phosphorus doses tested, 700 and $1050 \mathrm{mg} \mathrm{dm}^{-3}$ of $\mathrm{P}_{2} \mathrm{O}_{5}^{-}$, only led to satisfactory results when plants were under irrigation depths above $100 \% \mathrm{ETr}$, whereas plants subjected to 0 and $350 \mathrm{mg} \mathrm{dm}^{-3}$ of $\mathrm{P}_{2} \mathrm{O}_{5}{ }^{-}$showed superior dry matter accumulation when under irrigation depths of up to $100 \%$ ETr. It should be pointed out that the dry matter accumulation in plants irrigated with $80 \%$ ETr and cultivated in the substrate with addition of 0 and $350 \mathrm{mg} \mathrm{dm}^{-3}$ of $\mathrm{P}_{2} \mathrm{O}_{5}$ was similar to that of plants subjected to $100 \%$ ETr (Figure 2D). 
(A)

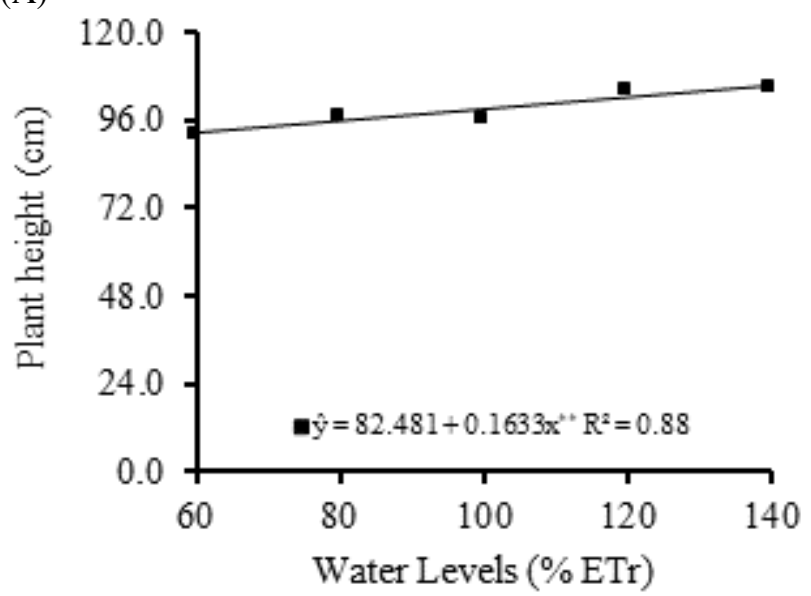

(C)

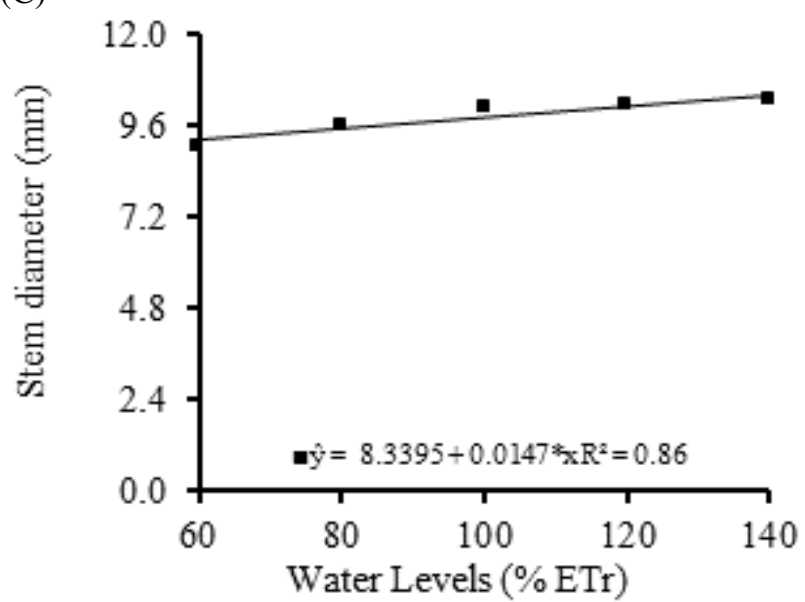

(B)

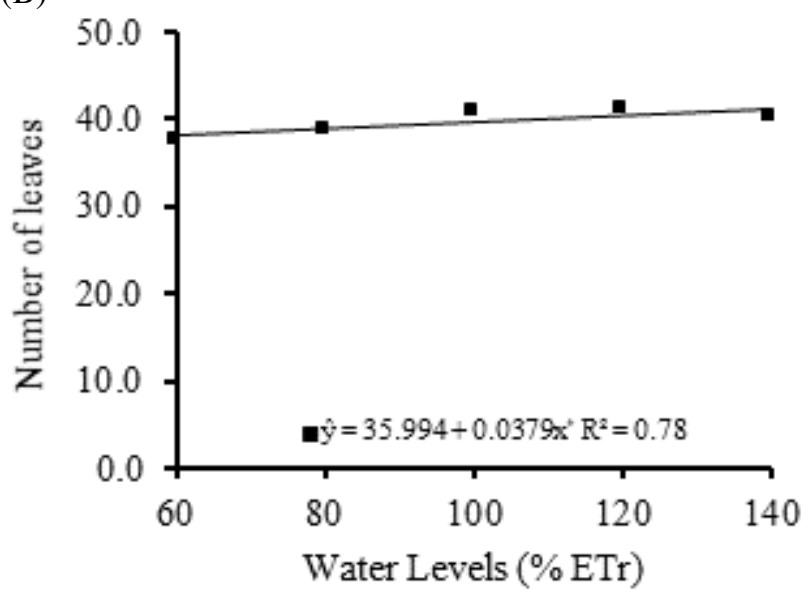

(D)

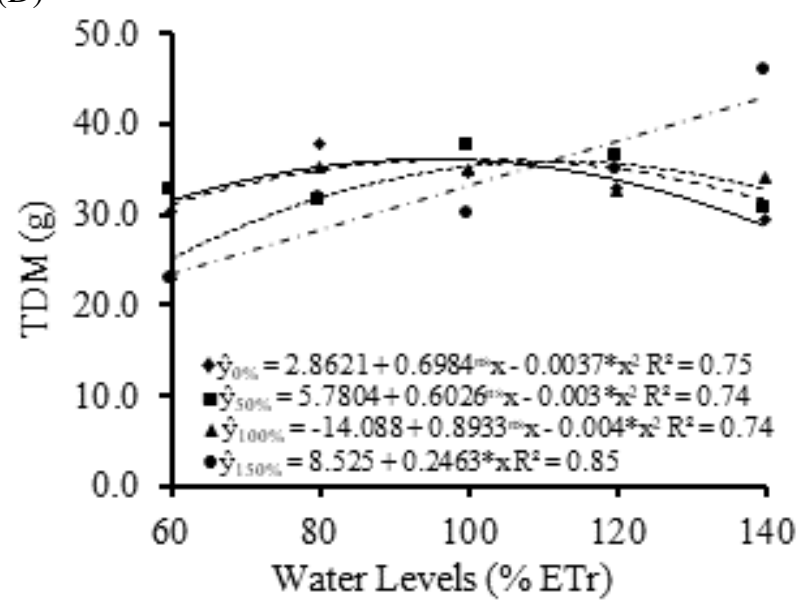

Figure 2. Plant height (A), number of leaves (B) and stem diameter (C) and total dry matter, TDM (D) of Annona squamosa L. seedlings as a function of the interaction between irrigation depths and phosphorus doses $\left(\diamond \mathrm{D} 1=0 ; \mathbf{\nabla D 2}=350 ; \boldsymbol{\Delta} \mathrm{D} 3=700\right.$ and $\bullet \mathrm{D} 4=1050 \mathrm{mg} \mathrm{dm}^{-3}$ of $\left.\mathrm{P}_{2} \mathrm{O}_{5}\right)$, at 120 days after treatments began to be applied.

According to Silva \& Farnezi (2009), the nutrients which most compromised the production of soursop (A. muricata) seedlings were $\mathrm{P}, \mathrm{N}, \mathrm{Ca}$ and $\mathrm{Mg}$. Considering the great demand for nutrients by Annonaceae plants, the substrates with higher contents of nutrients such as the phosphorus tested in the present study, are probably more promising for their growth. Nevertheless, very high doses of phosphorus in the form of single superphosphate maximized the effect of water stress on plants at the lowest water depths, probably due to the release of calcium sulfate salts and, consequently, reduction in osmotic potential. In addition, the positive responses at the highest doses of phosphorus associated with the highest irrigation depths may be related to the leaching of salts (SÁ et al., 2015; LIMA et al., 2017), especially calcium sulfate salts present in the phosphate fertilizer.

\section{CONCLUSIONS}

Phosphorus dose of $350 \mathrm{mg} \mathrm{dm}^{-3}$ leads to satisfactory dry matter accumulation in A. squamosa seedlings, especially under irrigation with $100 \%$ ETr.

Leaf water potential and gas exchanges of the A. squamosa are affected by water stress, through both lack and excess of water; stomatal conductance is the variable most sensitive to the lack of water, whereas photosynthesis and water use efficiency are the most sensitive to the excess of water.

Irrigation depth of $100 \% \mathrm{ETr}$ is ideal to produce $A$. squamosa seedlings, but the irrigation depth of $80 \%$ ETr can be used to produce these seedlings, disregarding small losses in growth. 
RESUMO: Objetivou-se avaliar o crescimento e a fisiologia de mudas de A. squamosa sob lâminas crescentes de irrigação e doses de fósforo. $\mathrm{O}$ experimento foi conduzido em ambiente protegido, avaliando cinco lâminas de irrigação e quatro doses $\mathrm{P}_{2} \mathrm{O}_{5}$, arranjados em esquema fatorial 5 x 4, em blocos casualizados, com quatro repetições e uma planta por parcela. Os tratamentos das lâminas foram 60, 80, 100, 120 e $140 \%$ da evapotranspiração real das mudas - ETr e as quatro doses de fósforo 0, 350, 700 e $1050 \mathrm{mg} \mathrm{dm}^{-3} \mathrm{de}_{2} \mathrm{O}_{5}$. As plantas foram avaliadas aos 120 dias após o transplantio, quanto ao crescimento, trocas gasosas, potencial hídrico foliar e acúmulo de matéria seca total. A dose de fósforo de $350 \mathrm{mg} \mathrm{dm}^{-3}$ proporciona acúmulo de matéria seca satisfatório para as mudas de A. squamosa, principalmente sob irrigação com $100 \%$ da ETr. O potencial hídrico foliar e as trocas gasosas da A. squamosa são afetadas pelo estresse hídrico, tanto por falta como por excesso de água, sendo a condutância estomática a variável mais sensível a falta de água e a fotossíntese e eficiência do uso da água as mais sensíveis ao excesso de água. A lâmina de $100 \%$ da ETr é a ideal para a produção de mudas de A. squamosa, porém a lamina de $80 \%$ da ETr pode ser utilizada para a produção de mudas de $A$. squamosa, admitindo-se pequenas perdas no crescimento.

PALAVRAS-CHAVE: Annonaceae: Disponibilidade hídrica: Trocas gasosas: Fertilidade do solo

\section{REFERENCES}

ARAÚJO, S. A. C.; DEMINICIS, B. B. Fotoinibição da fotossíntese. Revista Brasileira de Biociências, Porto Alegre, v. 7, n. 4, p. 463-472, out./dez. 2009.

AZEVEDO, B. M.; BASTOS; F. G. C; VIANA, T. V. A. de. Efeitos de níveis de irrigação na cultura da melancia. Revista Ciências Agronômica, Fortaleza, v. 36, n. 1, p. 9-15, mai. 2014.

BATISTA, C. U. N.; MEDRI, M. E.; BIANCHINI, E.; MEDRI, C.; PIMENTA, J. A. Tolerância à inundação de Cecropia pachystachya Trec. (Cecropiaceae): aspectos ecofisiológicos e morfoanatômicos. Acta Botanica Brasilica, São Paulo, v. 22, n. 1, p. 91-98, jan. 2008.

BENLLOCH-GONZÁLEZ, M.; ROMERA, C.; CRITESCU, S.; HARREN, F.; FOURNIER, J.M.; BENLLOCH, M. $\mathrm{K}^{+}$Starvation inhibits water-stress induced stomatal closure via ethylene synthesis in sunflower plants. Journal of Experimental Botany, Oxford, v. 61, n. 4, p. 1139-1145, mar. 2010. https://doi.org/10.1093/jxb/erp379

BERNARDO, S.; SOARES, A. A.; MANTOVANI, E. C. Manual de Irrigação. 8.ed. Viçosa: Editora UFV, 2008. 625p.

BOSCO, M. R. O.; OLIVEIRA, A. B.; HERNANDEZ, F. F. F.; LACERDA, C. F. Efeito do NaCl sobre o crescimento, fotossíntese e relações hídricas de plantas de berinjela. Revista Ceres, Viçosa, v. 56, n. 3, p. 296302, abr. 2009.

ENDRES, L.; SILVA, J. V.; FERREIRA, V. M.; BARBOSA, G. V. S. Photosynthesis and water relations in Barzilian Sugarcane. The Open Agriculture Journal, Sharjah, v .4, n. 1, p. 31-37, out. 2010. https://10.2174/1874331501004010031

FERREIRA, D. F. Sisvar: A computer statistical analysis system. Ciência e Agrotecnologia, Lavras, v.35, n. 6, p. 1039-1042, nov./dez. 2011. http://dx.doi.org/10.1590/S1413-70542011000600001

FREITAS, R. M. O.; NOGUEIRA, N. W.; PINTO, J. R. S.; TOSTA, M. S.; DOMBROSKI, J. L. D. Fertilizante fosfatado no desenvolvimento inicial de mudas de pinheira. Bioscience Journal, Uberlândia, v.29, n. 2, p. 319327, mar./abr. 2013.

GALMÉS, J.; RIBAS-CARBÓ, M.; MEDRANO, H.; FLEXAS, J. Rubiscoactivity in Mediterranean species is regulated by the $\mathrm{CO}_{2}$ concetration under water stress. Journal of Experimental Botany, Oxford, v. 62, n. 2, p. 653-665, jan. 2011. https://doi.org/10.1093/jxb/erq303 
LEMOS, E. E. P. A produção de Anonáceas no Brasil. Revista Brasileira de Fruticultura, Jaboticabal, v. 36, edição especial, p. 77-85, jan. 2014.

LIMA, Y. B.; SÁ, F. V. S.; FERREIRA NETO, M.; PAIVA, E. P.; GUEYI, H. R. Accumulation of salts in the soil and growth of cowpea under salinity and phosphorus fertilization. Revista Ciência Agronômica, Fortaleza, v. 48, n. 5, p. 765-773, jan. 2017. https://10.5935/1806-6690.20170089

MACHADO, D. F. S. P.; MACHADO, E. C.; MACHADO, R. S.; RIBEIRO, R. V. Efeito da baixa temperatura noturna e do porta-enxerto na variação diurna das trocas gasosas e na atividade fotoquímica de laranjeira 'Valência'. Revista Brasileira de Fruticultura, Jaboticabal, v. 32, n. 2, p. 351-359, jan. 2010.

MARTINS, J. D.; CARLESSO, R.; KNIES, J. D.; OLIVEIRA, Z. B.; BROETTO, T.; RODRIGUES, G. J. Potencial hídrico foliar em milho submetido ao déficit hídrico. Irriga, Botucatu, v. 15, n. 3, p. 324-334, jul./set. 2010. http://dx.doi.org/10.15809/irriga.2010v15n3p324

MEDEIROS, J. X. ; SILVA, G. H.; SANTOS, R. V. Crescimento inicial de mudas de pinheira e goiabeira em solo salino-sódico com corretivos. Revista Verde de Agroecologia e Desenvolvimento Sustentável, Pombal, v. 9, n. 2, p. 59-65, jun. 2014.

OLIVEIRA, A. K. M.; GUALTIERI, S. C. J. Trocas gasosas e grau de tolerância ao estresse hídrico induzido em plantas jovens de Tabebuia aurea (paratudo) submetidas a alagamento. Ciência Florestal, Santa Maria, v. 27, n. 1, p. 181-191, jan./mar. 2017. http://dx.doi.org/10.5902/1980509826457

PEREIRA, M. C. T.; BRAZ, L. C.; NIETSCHE, S.; MOTA, W. F. Determining the harvesting maturity of the sugar apple fruits on northern Minas Gerais. Acta Horticulturae, Korbeek-Lo, v. 864, n. 2, p. 207-214, jun. 2010. http://10.17660/ActaHortic.2010.864.27

QUEIROZ, T. B.; ROCHA, S. M. G.; FONSECA, F. S. A..; ALVARENGA, I. C. A.; A.; MARTINS, E. R. Efeitos do déficit hídrico no cultivo de mudas de eucalipto. Irriga, Botucatu, v. 22, n. 4, p. 659-674, out./dez. 2017. http://dx.doi.org/10.15809/irriga.2017v22n4p659-674

SÁ, F. V. S.; BRITO, M. E. B.; FERREIRA, I. B.; ANTONIO NETO, P.; SILVA, L. A.; COSTA, F. B. Balanço de sais e crescimento inicial de mudas de pinheira (Annona squamosa L.) sob substratos irrigados com água salina. Irriga, Botucatu, v. 20, n. 3, p. 544-556, jul./set. 2015.

http://dx.doi.org/10.15809/irriga.2015v20n3p544

SÁ, F. V. S.; GUEYI, H. R.; LIMA, G. S.; PAIVA, E. P.; FERNANDES, P. D.; MOREIRA, R. C. L.; SILVA, L. A.; MFERREIRA NETO, M. Water relations and gas exchanges of West Indian Cherry under salt stress and nitrogen and phosphorus doses. Journal of Agricultural Science, Toronto, v. 9, n. 10, p. 168-177, ago. 2017. https://doi.org/10.5539/jas.v9n10p168

SCHOLANDER, P. F.; BRADSTREET, E. D.: HEMMINGSEN, E. A.; HAMMEL, H. T. Sap pressure in vascular plants. Science, Washington, v. 148, n. 3668 p. 339-346, abr. 1965.

https://10.1126/science.148.3668.339

SILVA, C. A.; DOURADO NETO, D.; SILVA, C. J.; MELO, B. Desenvolvimento de mudas de pitangueira em função de lâminas de irrigação em dois tamanhos de recipiente. Irriga, Botucatu, v. 20, n. 4, p. 638-651, out./dez. 2015. http://dx.doi.org/10.15809/irriga.2015v20n4p638

SILVA, E. B.; FARNEZI, M. M. M. Limitações nutricionais para o crescimento de mudas de graviola em casa de vegetação em Latossolo vermelho distrófico do Norte de Minas Gerais. Bioscience Journal, Uberlândia, v. 25, n. 6, p. 52-58, nov./dez. 2009. 
SILVA, F. G.; DUTRA, W. F.; DUTRA, A. F.; OLIVEIRA, I. M.; FILGUEIRAS, L. M. B.; MELO, A. S. Trocas gasosas e fluorescência da clorofila em plantas de berinjela sob lâminas de irrigação. Revista Brasileira de Engenharia Agrícola e Ambiental, Campina Grande, v. 19, n. 10, p. 946-952, out. 2015.

http://dx.doi.org/10.1590/1807-1929/agriambi.v19n10p946-952

TAIZ, L.; ZEIGER, E.; MØLLER, I. M.; MURPHY, A. Plant physiology and development.6.ed., New York: Sinauer Associates, 2015.761p. 